\title{
STUDI PENDAHULUAN : EMOSI MORAL PADA REMAJA
}

\author{
MM Shinta Pratiwi \\ Fakultas Psikologi Universitas Semarang \\ shinta_psiusm@yahoo.co.id \\ Maria Goretti Adiyanti \\ Fakultas Psikologi Universitas Gadjah Mada
}

\begin{abstract}
Abstrak
Perkembangan dalam aspek moral sangat penting untuk diperhatikan terutama pada masa remaja. Salah satu aspek penting dalam perkembangan moral adalah emosi moral. Tujuan dari penelitian ini adalah melakukan studi awal dari penelitian tentang emosi moral guna mengetahui macam-macam pelanggaran moral pada remaja, macam-macam emosi moral remaja, dan faktor-faktor yang mempengaruhi munculnya emosi moral. Penelitian awal ini dilakukan dengan menggunakan studi survey pada 276 remaja usia 10 - 19 tahun di Semarang. Analisis data yang digunakan adalah dengan menghitung frekuensi serta prosentase. Pelanggaran moral yang paling banyak dialami oleh remaja adalah mencotek, Perilaku bully, perilaku berpacaran berisiko melanggar peraturan sekolah, melanggar peraturan lalu lintas, berbohong, merokok, membantah orangtua, berkelahi , menonton film porno, dan mencuri. Emosi moral yang muncul pada remaja adalah takut, sedih, bingung, prihatin, merasa bersalah,jijik, gelisah, kecewa, biasa saja, kasihan, kawatir, dan senang. Faktor yang paling kuat memunculkan emosi moral terdiri dari dua faktor yaitu eksternal (seperti pengaruh orang tua,teman, dan guru) dan internal(seperti nilai yang dimiliki, karakter dan identitas moral)..
\end{abstract}

Kata kunci : emosi moral, pelanggaran moral.

\begin{abstract}
Moral development is considered crucial across the human life course, especially during adolescence. One of important part of morality is moral emotion. This study aimed to preliminary explore the various types of moral transgression, the various forms of moral emotions, and the factors that influence the emerge of moral emotions, through exploratory survey research. Participants were 276 adolescents living in Semarang, aged 10 to 19 years. Descriptive analysis were used to calculate the percentages and the frequencies with regard to the total amount of responses. Results showed that the most common moral transgression in adolescents was cheating, followed by bullying, risky dating behavior, breaking school's rules, breaking traffic's rules, lying, smoking, arguing parents, fighting, watching porn movies, and stealing. Moral emotions that appeared among adolescents were fear, sad, confused, concerned, guilty, disgusted, anxious, disappointed, so-so/neutral, pity, worried, and happy. The appearance of moral emotions influenced by two factors: external (i.e., the influence of parents, peer, and teacher) and internal (i.e., value, character and moral identity).
\end{abstract}

Keywords: moral emotion, moral transgression

(C) 2018 Universitas Muria Kudus 


\section{PENDAHULUAN}

Perkembangan dalam aspek moral sangat penting untuk diperhatikan terutama pada masa remaja. Aspek ini merupakan kebutuhan penting bagi remaja, terutama sebagai pedoman menemukan identitas dirinya, mengembangkan hubungan personal yang harmonis dan menghindari konflik-konflik peran yang selalu terjadi dalam masa transisi (Desmita, 2005).

Menurut Sawyer, Azzopardi, Wickremarathne, \& Patton (2018) batas usia remaja yang lebih sesuai dengan pertumbuhan dan pemahaman remaja adalah usia 10 - 24 tahun. Menurut WHO, usia remaja adalah antara usia 10 - 19 tahun. Masa remaja merupakan fase kehidupan yang membentang antara masa kanak-kanak dan dewasa. Masa remaja mencakup unsur pertumbuhan biologis dan transisi peran sosial utama. Masa remaja sendiri merupakan masa mencari jati diri, dan berusaha melepaskan diri dari lingkungan orang tua untuk menemukan jati dirinya maka masa remaja menjadi suatu periode yang sangat penting dalam pembentukan nilai (Monks, Knoers, \& Haditono, 2000). Salah satu karakteristik remaja yang sangat menonjol berkaitan dengan nilai adalah bahwa remaja sudah sangat merasakan pentingnya tata nilai dan mengembangkan nilai-nilai baru yang sangat diperlukan sebagai pedoman, pegangan, atau petunjuk dalam mencari jalannya sendiri untuk menumbuhkan identitas diri menuju kepribadian yang semakin matang.

Namun demikian, sayangnya masalah dekandensi moral tidak pernah sepi dari perbincangan karena kasus-kasus yang berkaitan dengan perilaku amoral tidak menurun tapi justru meningkat dengan pesat. Salah satu domain moral yang memiliki fungsi untuk memotivasi perilaku moral adalah emosi moral (Tangney \& Dearing, 2004). Oleh karena itu, emosi moral merupakan satu domain perkembangan moral yan perlu diteliti lebih lanjut. Tujuan penelitian ini adalah untuk mengetahui pelanggaran moral apa saja yang dilakukan oleh remaja, emosi moral apa saja yang muncul, dan faktor apa saja yang menginspirasi munculnya emosi moral.

Moralitas secara umum dikaitkan dengan nilai-nilai kemanusiaan dan berhubungan dengan perilaku yang boleh atau tidak boleh dilakukan. Moralitas tidak semata-mata berhubungan dengan perilaku yang terlihat ataupun yang dapat diketahui dari berita (misalnya berita-berita kriminal), akan tetapi lebih dalam dari sekedar perilaku yang tampak tersebut. Dalam menilai suatu perilaku boleh atau tidak boleh dilakukan, pertimbangan atau pemikiran yang mendasari terjadinya penilaian moral itu merupakan hal yang patut untuk diperhatikan. Santrock (2003) perkembangan moral berhubungan dengan peraturan-peraturan dan nilainilai mengenai apa yang harus dilakukan seseorang dalam interaksinya dengan orang lain. Tiga domain dalam perkembangan moral adaah pemikiran moral, tingkah laku moral, dan emosi moral. Ketiga domain tersebut tidak dapat terpisah satu persatu, namun memiliki keterkaitan. 
Selama ini, penelitian yang banyak dilakukan lebih kepada pemikiran moral. Rest (1999) teori Kohlberg lebih memfokuskan pada penalaran moral namun kurang mementingkan aspek fungsi moral. Menurut William Kilpatrick (Muslich, 2013) salah satu penyebab ketidakmampuan seseorang untuk berperilaku baik, walaupun secara kognitif ia mengetahuinya (moral knowing), yaitu karena tidak terlatih untuk melakukan kebajikan atau moral action. Dalam pendidikan karakter, Lickona (1992) menekankan pentingnya tiga komponen karakter yang baik, yaitu moral knowing atau pengetahuan tentang moral, moral feeling atau perasaan tentang moral, dan moral action atau perbuatan moral. Hal ini diperlukan agar mampu memahami, merasakan dan mengerjakan sekaligus nilai-nilai kebajikan. Menurut Borba (2001) penalaran dan penilaian moral saja tidak cukup namun perlu disertai dengan perilaku moral yang tergolong baik karena perkembangan moral sebaiknya mencakup aspek penalaran, perasaan, perilaku, dan kepribadian tentang standar mengenai benar dan salah. Oleh karena itu, penting bagi anak untuk mengetahui dan mampu melakukan tindakan benar dan salah tidak hanya mengetahui pesan moral dari orangtua saja.

Teori perkembangan moral yang banyak dibahas adalah teori dari Piaget dan Kohlberg. Kedua teori tersebut lebih menekankan peran kognitif bagi perkembangan moral dan melihat kematangan moral lebih pada kognitifnya. Menurut Santrock (2003) teori Kohlberg lebih menekankan pada pemikiran moral dan kurang menekankan pada tingkah laku moral. Alasan-alasan moral kadang kala dapat menjadi tempat berlindungnya tingkah laku yang tidak bermoral. Hal tersebut banyak ditentang oleh para peneliti, karena dengan hanya menekankan pada aspek kognitif saja, kita tidak akan dapat mengetahui alasan mengapa pertimbangan kognisinya benar namun tingkah laku yang ditunjukkan tidak sama dengan pertimbangannya.

Pertimbangan tersebut diatas, membuat penulis menilik lebih lanjut pada domain perkembangan moral lainnya yang tidak kalah pentingnya yaitu emosi moral. Oleh Santrock (2003) dituliskan bahwa emosi moral berkaitan dengan perasaan apa yang muncul saat seseorang melakukan pelanggaran moral. Apakah rasa bersalah dalam diri remaja membuatnya tidak akan mengulang perilaku yang sama?

Ada berbagai definisi yang menjelaskan tentang emosi moral. Menurut Santrock (2003) teori Freud memberikan kejelasan awal mengenai emosi moral. Superego sebagai satu dari tiga struktur kepribadian merupakan cabang moral dari kepribadian. Dalam penjelasannya, perasaan bersalah akan mencegah anak dan para remaja dalam melakukan kesalahan, sehingga anak dan remaja mampu menyesuaikan diri dengan strandart masyarakat untuk menghindari rasa bersalah. Sigelman dan Shaffer (1991) menjelaskan bahwa emosi moral merupakan salah satu komponen dari perkembangan yang melingkupi perbuatan benar atau salah dan memotivasi pikiran dan perilaku-perilaku lainnya. Menurut Shaffer dan Kipp (2014) perasaan moral merupakan salah satu komponent dari 
perkembangan moral yang didalamnya termasuk perasaan-perasaan seperti rasa bersalah, malu, dan bangga dalan perilaku etis. Haidt (2003) mendefinisikan emosi moral berkaitan dengan kepentingan atau kesejahteraan baik dari masyarakat secara keseluruhan atau setidaknya orang lain selain sebagai "agent ". Emosi moral adalah emosi yang merespon pelanggaran moral dan yang memotivasi individu untuk memilih perilaku moral tertentu. Emosi moral memiliki kekuatan untuk memotivasi untuk berbuat baik dan menghindari melakukan hal buruk (Tangney, Stuewig, \& Mashek, 2006). Menurut Haidt (2003) ada dua komponen yang berguna untuk mengidentifikasi emosi moral, yaitu menggerakkan seseorang yang semula tidak berminat (disinterested elicitor) dan kemampuan untuk menggerakkan kecenderungan perilaku individu kearah kebaikan (prososial action tendencies)

Menurut Stests \& Turner (2006 ) emosi moral menghubungkan orang dengan struktur sosial dan budaya melalui kesadaran diri. Struktur sosial berada diantara budaya dan individu. Beberapa kode budaya seperti nila-nilai yang umum melekat pada individu-individu yang memainkan peranya pada system sosial yang ada. Kode budaya lainnya misalnya normanorma akan memainkan perannya dalam situasi setempat sesuai dengan kondisi dan konteksnya.

Menurut Haidt (2003) dan Stests \& Turner (2006) ada empat kelompok emosi moral, yaitu :

\section{Self-Critical Moral Emotions: Shame and Guilt}

Oleh Haidt (2003) disebut dengan The Self-Conscious Emotions. Emosi moral ini merupakan emosi negatif yang diarahkan pada diri karena melanggar kode moral. Rasa malu dan rasa bersalah timbul ketika individu atau orang lain dalam situasi tertentu merasa bahwa telah terjadi pelanggaran kode budaya atau kegagalan untuk hidup. Menurut Tangney \& Tracy (2011) Self-Conscious Emotions terdiri dari shame, guilt, embarrassment, and pride yang ditimbulkan oleh refleksi diri dan evaluasi diri.

\section{Other-Critical Moral Emotions: Contempt, Anger, and Disgust}

Oleh Haidt (2003) disebut dengan istilah The Other-Condemning Emotions. Contempt, Anger, dan Disgust adalah reaksi terhadap pelanggaran moral orang lain. Contempt berada diantara anger dan disgust (Haidt, 2003). Emosi ini merupakan emosi negatif yang diarahkan pada orang lain untuk pelanggaran kode moral. Rozin dan rekan-rekannya (Rozin, Lowery, Imada, \& Haidt, 1999) menyatakan bahwa Contempt, Anger, dan Disgust muncul di seluruh budaya ketika ada pelanggaran di tiga kode moral: masyarakat, otonomi, dan keilahian.

3. Other-Suffering: Empathy and Sympathy

Emosi ini adalah perasaan negatif yang terkait dengan menyaksikan pengalaman atau sesuatu yang buruk. Empati dan simpati dapat dibedakan dengan cara berikut. Empati melibatkan kemampuan untuk memahami keadaan afektif dari (komponen kognitif) lain atau benar-benar merasakan emosi yang terasa lain (komponen afektif) melalui mengambil 
perspektif lain. Simpati tidak begitu banyak melibatkan pengalami emosi yang lain sebagai upaya untuk memahami kesulitan yang dihadapi oleh orang lain dan untuk memancarkan tanggapan mendukung dan peduli. Ini adalah kemampuan untuk memahami penderitaan lain dan untuk memancarkan variasi kesedihan, ditambah dengan dukungan untuk situasi lain (Stets \& Turner, 2006). Empati tidak diperlukan untuk simpati; memang, salah satu bisa merasakan simpati lain tetapi tidak memiliki reaksi empatik yang lain. Sebagai contoh, seseorang dapat memiliki perhatian dan kepedulian bagi orang lain tetapi belum tentu merasakan apa yang dirasa orang lain. Selain itu, salah satu bisa merasakan empati untuk yang lain, tapi empati ini tidak menimbulkan perasaan simpati mungkin karena yang lain dinilai layak dengan apa yang menimpanya.

\section{Other-Praising Moral Emotions: Gratitude dan Elevation}

Rasa syukur sangat penting dalam menjaga kehidupan bermasyarakat. Rasa syukur, mengungkapkan perasaan yang menyenangkan karena telah diberikan nasib baik. Stets dan Turner (2006) telah menguraikan rasa syukur merupakan emosi moral. Rasa syukur memiliki tiga fungsi moral yaitu sebagai barometer moral, motif moral, dan penguat moral. Sebagai barometer moral, rasa syukur adalah respons terhadap kemurahan hati orang lain. Hubungan sosial antara dua individu telah berubah, dan satu telah mendapatkan manfaat dari tindakan kebajikan yang lain. Syukur juga motif moral karena itu mendorong orang berterima kasih untuk berperilaku murah hati. Rasa syukur dapat mendasari timbal balik altruisme (Stets \& Turner, 2006). Rasa syukur dapat memotivasi seseorang untuk lebih bersikap prososial.

Terkait dengan perasaan syukur adalah elevasi. Ini adalah perasaan kehangatan dan ekspansi yang terkait dengan menyaksikan tindakan amal, kebaikan, dan pengorbanan diri bahwa alam nyata manusia yang lebih tinggi (Haidt 2003). Ada perasaan positif kagum dan takjub. Haidt (2003) menunjukkan, elevasi adalah kebalikan dari jijik. Sedangkan jijik muncul ketika orang-orang mengaburkan batas bawah dari manusia, elevasi terjadi ketika orang mengaburkan batas atas manusia dan ilahi. Elevasi adalah untuk mencari kontak dan menyentuh hadirat seseorang. Elevasi adalah tanggapan moral yang berkaitan dengan keindahan; jijik adalah reaksi terhadap kebejatan moral.

Syukur dan elevasi adalah emosi positif yang mendorong perilaku prososial. Sedangkan syukur memotivasi perilaku prososial yang bersifat lokal karena tindakan itu kemungkinan besar akan diarahkan pada orang lain, elevasi mendorong tindakan membantu, kebaikan, dan amal yang bersifat umum, memotivasi seseorang untuk menjadi orang yang lebih baik dan mengikuti contoh moral.

Menurut Haidt (2003) terdapat emosi moral lain yaitu fear dan love. Fear umumnya memicu kekhawatiran tentang diri (atau kerabat terdekat diri ini). Sebuah pertanyaan yang lebih sulit adalah emosi love. Love pasti membedakan Homo sapiens dari Homo economicus. Love dapat memunculkan kecenderungan melakukan perilaku prososial dan pengorbanan 
diri. serta setidaknya salah satu bentuk kasih agape (cinta tanpa pamrih dan tanpa syarat). Agape adalah emosi sentral dalam sistem etika pada banyak agama.

Beberapa penelitian sudah dilakukan di luar Indonesia, namun penelitian di Indonesia belum banyak. Salah satunya penelitian Jia (2008) pada remaja di Kanada dan di Cina menemukan bahwa ada perbedaan budaya yang sistematis dalam emosi moral; Namun, perbedaan ini hanya sebagian disebabkan penilaian moral. Penelitian ini juga menunjukkan bahwa faktor kognitif dan kontekstual mempengaruhi moral emosional yang diharapkan, bersama dengan penalaran dan penilaian. Penelitian ini memberikan hasil empiris dari konsekuensi emosional ketika orang menghadapi konflik sehari-hari di berbagai jenis domain moral dalam perspektif lintas budaya. Oleh karena itu penulis ingin mengkaji lebih dalam berkaitan dengan emosi moral khususnya pada remaja di Semarang.

Rudolph (2013) menjelaskan bahwa emosi dapat diklasifikasikan menjadi dua berdasarkan (1) tujuan atau targetnya yaitu (a) emosi sebagai actor emotions yang muncul karena ditargetkan pada perbuatannya sendiri. Kondisi ini sama dengan yang disebut selfconscious (Haidt, 2003; Tangney, Stuewig, \& Mashek, 2007) atau self-directed (Weiner, 2006) dan (b) Observer emotions lebih berkaitan dengan bagaimana individu hanya sebagai pengamat saja. Emosi moral dianggap sebagai persepsinya terhadap tingkah laku orang lain (misalnya, kekaguman, kemarahan, rasa syukur, dan simpati (Weiner, 2006 \& Haidt, 2003).

Klasifikasi yang ke (2) ), emosi moral berfungsi untuk mengatur perilaku sosial (Fiske, 2002;Greene, 2003; Haidt, 2003; Tangney et al., 2007; Weiner,2006). Oleh karena itu oleh Rudolph (2013); Haidt (2003); Lewis (2008) emosi moral akan mengevaluasi tindakan seseorang baik secara positif atau negatif. Kriteria ini berlaku untuk kedua emosi moral yaitu actor emotions, mengevaluasi tindakan sendiri sebagai baik atau buruk serta observer emotions, mengevaluasi tindakan orang lain sebagai baik atau buruk atau terpuji atau tercela. Lebih lanjut dijelaskan oleh Rudolph (2013) berkaitan dengan lasifikasi emosi moral berdasarkan fungsi evaluasi perilaku, yaitu :

\section{Actor emotions.}

Actor emotions positif terdiri dari bangga ( tanda dimana orang merasa telah melakukan Sesuatu yang baik atau layak dipuji dan dapat memotivasi dirinya. Sebaliknya, actor emotions negative yaitu yaitu, malu, rasa bersalah, menyesal, malu yang merupakan tanda bahwa seseorang melakukan sesuatu yang salah atau buruk, bahwa orang tersebut dapat disalahkan dan harus mengubah perilaku.

\section{Observer emotions.}

Fungsi regulatif diterapkan untuk Observer emotions, kecuali bahwa sinyal evaluatif dalam hal ini diarahkan pada orang yang diamati. Menyesal dan malu merupakan tanda bahwa sinyal bahwa seseorang melakukan sesuatu yang salah atau buruk, bahwa orang tersebut dapat disalahkan dan harus mengubah perilaku. 


\section{METODE PENELITIAN}

Penelitian pendahuluan ini merupakan penelitian survei. Menurut Irawan (2007) metode survei adalah metode penelitian yang menggunakan kuesioner sebagai instrumen utama untuk mengumpulkan data. Metode penelitian yang dipakai adalah penelitian survei yang bersifat deskriptif-eksploratif adalah penelitian yang digunakan untuk mengumpulkan data-data awal tentang sesuatu. Ada dua tahap yang dilakukan pada penelitian ini. Tahap 1 adalah menanyakan pelanggaran moral apa saja yang dilakukan oleh remaja. Tahap 2 adalah membuat induksi yang berupa cerita yang berisi dilema moral berdasarkan pelanggaran moral yang dilakukan. Tugas yang harus dilakukan oleh partisipan adalah membaca cerita-cerita yang berisi dilema moral, menjawab pertanyaan setelah membaca cerita dilema moral. Pertanyaan yang diberikan adalah berkiatan dengan apa yang akan dilakukan, perasaan apa yang mendasari keputusan, dan faktor apa yang menginspirasi munculnya emosi. Contoh satu cerita yang digunakan "Saat ulangan, tiba-tiba guru saya harus meninggalkan ruangan karena dipanggil kepala sekolah dan tidak ada guru pengganti. Situasi tersebut membuat kami tergoda untuk mencontek, bekerja sama dan bertanya dengan teman lain agar nilai ulangan baik. Nilai ulangan yang diperoleh adalah salah satu penentu untuk kenaikan kelas" (a) Apa yang akan saya lakukan? (b) Emosi apa yang mendasari keputusan saya? (c) Faktor apa yang menginsipirasi munculnya emosi tersebut?

Partisipan penelitian adalah remaja putra dan putri usia 10 tahun - 19 tahun berjumlah 276 di Kecamatan Banyumanik, Semarang. Penentuan subyek dilakukan dengan teknik sample incidental sesuai dengan tujuan penelitian.

Analisis data dilakukan adalah analisis deskripssi dengan cara menghitung frekuensi dan prosentase pelanggaran moral yang muncul, emosi moral yang muncul, dan faktor apa saja yang menginsipirasi munculnya emosi moral.

\section{HASIL DAN PEMBAHASAN}

Hasil yang ditemukan pada tahap 1 adalah macam-macam pelanggaran moral. Partisipan boleh menuliskan lebih dari satu pelanggaran moral apa saja yang dilakukan. Adapun hasilnya ada pada tabel

Tabel 1. Pelanggaran moral remaja

\begin{tabular}{llll}
\hline No. & \multicolumn{1}{c}{ Pelanggaran moral } & Jumlah & $\begin{array}{c}\text { Prosentase dari } \\
276\end{array}$ \\
\hline 1. & Mencontek & 179 & $65 \%$ \\
\hline 2. & Perilaku Bully & 94 & $34 \%$ \\
\hline 3. & Perilaku berpacaran yang berisiko & 83 & $30 \%$ \\
\hline 4. & Melanggar peraturan sekolah & 69 & $25 \%$ \\
\hline 5. & Melanggar peraturan lalu lintas & 41 & $15 \%$ \\
\hline 6. & Berbohong & 41 & $15 \%$ \\
\hline 7. & Merokok & 36 & $13 \%$ \\
\hline
\end{tabular}




\begin{tabular}{llll}
\hline 8. & Membantah orangtua & 36 & $13 \%$ \\
\hline 9. & perkelahian & 33 & $12 \%$ \\
\hline 10. & Menonton film porno & 27 & $10 \%$ \\
\hline 11. & Mencuri & 17 & $6 \%$ \\
\hline
\end{tabular}

Hasil yang ditemukan pada tahap 2 adalah macam-macam emosi moral yang muncul pada remaja berdasarkan masing-masing persoalan moral. Pada tabel 2 disajikan hasil dari berbagai macam emosi moral yang mucul pada remaja laki-laki dan perempuan.

Tabel 2 . Rata-rata Prosentase Emosi Moral Remaja Laki-laki \& Perempuan

\begin{tabular}{|c|c|c|c|c|}
\hline No & Emosi & Laki-laki & Perempuan & Rata-rata \\
\hline 1 & Sedih & 19 & 23 & 21 \\
\hline 2 & Bingung & 14,7 & 23,4 & 19,05 \\
\hline 3 & Takut & 9,1 & 18,8 & 13,95 \\
\hline 4 & Gelisah & 6 & 14 & 10 \\
\hline 5 & Senang & 9,1 & 0,2 & 4,65 \\
\hline 6 & Prihatin & 2,4 & 6,8 & 4,6 \\
\hline 7 & Biasa saja & 6 & 0,9 & 3,45 \\
\hline 8 & Merasa bersalah & 0,8 & 5,9 & 3,35 \\
\hline 9 & Kecewa & 3,6 & 3,1 & 3,35 \\
\hline 10 & Kasihan & 2,4 & 2,67 & 2,54 \\
\hline 11 & Marah & 2,6 & 1,9 & 2,25 \\
\hline 12 & Jengkel & 0,8 & 3,17 & 1,99 \\
\hline 13 & Jijik & 0,8 & 2,3 & 1,55 \\
\hline 14 & Miris & 0 & 0,7 & 0,35 \\
\hline 15 & Tidak senang & 0 & 0,7 & 0,35 \\
\hline 16 & Penasaran & 0 & 0,5 & 0,25 \\
\hline 17 & Menyesal & 0 & 0,5 & 0,25 \\
\hline 18 & Risih & 0 & 0,5 & 0,25 \\
\hline 19 & Berdosa & 0 & 0,2 & 0,1 \\
\hline 20 & Malu & 1,6 & 0 & 0,8 \\
\hline
\end{tabular}

Berdasarkan tabel 2, maka dapat diketahui bahwa emosi moral yang banyak dirasakan remaja baik putra dan putri adalah sedih, bingung, takut, gelisah, senang, dan prihatin. Sedangkan perasaan yang paling jarang muncul adalah malu, merasa berdosa, risih, menyesal, penasaran, miris, dan tidak suka. Sedangkan, 5 emosi moral yang banyak muncul pada remaja putri adalah bingung, sedih, takut, prihatin, dan rasa bersalah. Sedangkan lima emosi moral yang jarang muncul adalah merasa berdosa, senang, rishi, menyesal, dan rasa penasaran. Emosi moral pada remaja laki-laki yang banyak muncul yaitu sedih, bingung, takut, senang, biasa saja, dan gelisah. Sedangkan yang jumlahnya sedikit adalah perasaan bersalah, jengkel, dan jijik. 
Tabel 3. Respon emosi pada pernyataan tentang perkelahian (dalam \%)

\begin{tabular}{|c|c|c|c|}
\hline No & Emosi & Laki-laki & Perempuan \\
\hline 1 & Bingung & 38 & 70 \\
\hline 2 & Sedih & 31 & 23 \\
\hline 3 & Takut & 2 & 7 \\
\hline 4 & Prihatin & 0 & 6 \\
\hline 5 & Merasa bersalah & 2 & 1 \\
\hline 6 & Gelisah & 0 & 6 \\
\hline 7 & Kecewa & 2 & 1 \\
\hline 8 & Biasa saja & 5 & 0 \\
\hline 9 & Kasihan & 2 & 3 \\
\hline 10 & Senang & 2 & 1 \\
\hline 11 & Sakit hati & 2 & 0 \\
\hline 12 & Malu & 2 & 0 \\
\hline 13 & Tertekan & 5 & 0 \\
\hline
\end{tabular}

Berdasarkan tabel 3. menunjukkan bahwa baik remaja putra maupun putri bingung, sedih, takut, kasihan, kecewa, dan merasa bersalah pada saat harus menghadapi peristiwa perkelahian. Remaja putra merasa sakit hati, malu, dan tertekan dengan peristiwa perkelahian, namun tidak merasa gelisah dan prihatin. Sedang remaja putri merasa prihatin dan gelisah dengan adanya perkelahian. Namun demikian, masih ada juga yang merasa senang pada saat menghadapi perkelahian.

Tabel 4. Respon emosi pada pernyataan tentang mencontek (dalam \%)

\begin{tabular}{|c|c|c|c|}
\hline No & Emosi & Laki-laki & Perempuan \\
\hline 1 & Senang & 43 & 0 \\
\hline 2 & Bingung & 17 & 14 \\
\hline 3 & Takut & 14 & 31 \\
\hline 4 & Gelisah & 12 & 4 \\
\hline 5 & Sedih & 7 & 15 \\
\hline 6 & Prihatin & 5 & 7 \\
\hline 7 & Merasa bersalah & 0 & 8 \\
\hline 8 & Kecewa & 5 & 0 \\
\hline 9 & Jengkel & 0 & 6 \\
\hline 10 & Marah & 0 & 1 \\
\hline 11 & Biasa saja & 10 & 3 \\
\hline 12 & Kasihan & 0 & 1 \\
\hline 13 & Miris & 0 & 1 \\
\hline 14 & Tidak senang & 2 & 1 \\
\hline 15 & Grogi & 2 & 0 \\
\hline 16 & Tenang & 2 & 0 \\
\hline 17 & Malu & 5 & 0 \\
\hline
\end{tabular}




\begin{tabular}{llll}
18 & Terbebani & 2 & 0 \\
\hline 19 & Berdosa & 0 & 1 \\
\hline 20 & Menyesal & 0 & 3 \\
\hline
\end{tabular}

Tabel 4. menunjukkan respon emosi remaja pada dilema perilaku mencontek. Remaja putra merasa senang apabila mendapat kesempatan mencontek, sedangkan remaja putri lebih merasa takut, bingung, sedih, gelisah, pada saat mencontek sehingga ada yang merasa berdosa dan menyesal. Remaja putri tidak senang pada saat melihat temannya mencontek karena merasa tidak adil. Muncul perasaan prihatin pada diri remaja tentang perilaku mencontek, walaupun tidak banyak yang memiliki rasa tersebut. Bahkan pada beberapa remaja, perilaku mencontek adalah perilaku yang biasa saja dan tenang pada saat melakukannya. Rasa bersalah muncul pada remaja putri, namun tidak muncul pada remaja putra.

Tabel 5. Respon emosi pada pernyataan tentang bullying (dalam \%)

\begin{tabular}{|c|c|c|c|}
\hline No & Emosi & Laki-laki & Perempuan \\
\hline 1 & Sedih & 19 & 24 \\
\hline 2 & Bingung & 2 & 15 \\
\hline 3 & Prihatin & 7 & 14 \\
\hline 4 & Kecewa & 2 & 14 \\
\hline 5 & Gelisah & 5 & 4 \\
\hline 6 & Marah & 7 & 7 \\
\hline 7 & Jengkel & 5 & 7 \\
\hline 8 & Biasa saja & 12 & 3 \\
\hline 9 & Senang & 17 & 0 \\
\hline 10 & Kasihan & 14 & 0 \\
\hline 11 & Takut & 0 & 6 \\
\hline 12 & Tidak senang & 2 & 1 \\
\hline 13 & Aneh & 2 & 0 \\
\hline 14 & Grogi & 2 & 0 \\
\hline 15 & Sakit hati & 2 & 0 \\
\hline
\end{tabular}

Tabel 5. menunjukkan respon emosi remaja terhadap perilaku bullying. Sebagian besar merasa sedih pada saat menghadap peristiwa ini, bingung bagaimana menghadapinya, prihatin, gelisah, marah, kecewa, jengkel, dan tidak senang. Namun ternyata, perilaku ini banyak dilakukan oleh remaja dan remaja putra merasa biasa saja pada saat membully temannya. Bahkan ada yang beranggapan bahwa perilaku ini ada hal yang umum dan cukup menggelikan, sehingga senang melakukan. 
Tabel 6. Respon emosi pada pernyataan tentang berbohong pada orangtua (dalam \%)

\begin{tabular}{|c|c|c|c|}
\hline No & Emosi & Laki-laki & Perempuan \\
\hline 1 & Takut & 29 & 39 \\
\hline 2 & Merasa bersalah & 2 & 24 \\
\hline 3 & Bingung & 5 & 8 \\
\hline 4 & Sedih & 0 & 6 \\
\hline 5 & Prihatin & 0 & 1 \\
\hline 6 & Gelisah & 19 & 1 \\
\hline 7 & Penasaran & 0 & 1 \\
\hline 8 & Senang & 5 & 0 \\
\hline 9 & Malu & 2 & 0 \\
\hline 10 & Panik & 0 & 2 \\
\hline
\end{tabular}

Tabel 6. menunjukkan bahwa sebagian besar remaja merasa takut dimarahi pada saat berbohong pada orangtuanya. Remaja merasa gelisah, kawatir, tidak tenang, bingung, dan merasa bersalah pada saat berbohong. Rasa bersalah lebih banyak dialami oleh remaja putri daripada remaja putra. Namun remaja putra paling banyak merasa gelisah pada saat berbohong, senang berbohong, namun ada pula yang merasa malu.

Tabel 7. Respon emosi pada pernyataan tentang menonton film dewasa (dalam \%)

\begin{tabular}{|c|c|c|c|}
\hline No & Emosi & Laki-laki & Perempuan \\
\hline 1 & Jijik & 5 & 14 \\
\hline 2 & Sedih & 14 & 13 \\
\hline 3 & Takut & 2 & 10 \\
\hline 4 & Prihatin & 2 & 10 \\
\hline 5 & Kecewa & 12 & 3 \\
\hline 6 & Marah & 5 & 3 \\
\hline 7 & Bingung & 5 & 4 \\
\hline 8 & Biasa saja & 7 & 1 \\
\hline 9 & Merasa bersalah & 0 & 1 \\
\hline 10 & Jengkel & 0 & 6 \\
\hline 11 & Miris & 0 & 1 \\
\hline 12 & Tidak senang & 0 & 2 \\
\hline 13 & Penasaran & 2 & 1 \\
\hline 14 & Risih & 0 & 3 \\
\hline 15 & Gugup & 2 & 0 \\
\hline 16 & Aneh & 0 & 2 \\
\hline
\end{tabular}

Pada tabel 7. Menunjukkan bahwa remaja merasa sedih, jijik, kecewa, marah, takut, prihatin, dan bingung pada saat menghadapi tontonan film dewasa. Ada remaja yang penasaran ingin menonton. Ada pula remaja yang merasa biasa saja untuk menonton film dewasa, walaupun ada juga yang merasa gugup. Remaja puri lebih merasa risih, miris, dan 
prihatin dengan situasi tersebut sehingga jengkel bila tahu ada temannya yang menonton film dewasa.

Tabel 8. Faktor yang menginspirasi emosi moral (1 orang bisa beberapa faktor)

\begin{tabular}{l|l|c|c}
\hline No & Faktor-faktor & Jumlah partisipan & Prosentase \\
\hline 1. & $\begin{array}{l}\text { Orang tua : } \\
\text { - Ajaran orang tua. } \\
\text { - Melihat orang tua. } \\
\text { - Dukungan orang tua untuk } \\
\text { mengekspresikan emosi. }\end{array}$ & 86 \\
\hline 2. & $\begin{array}{l}\text { Diri sendiri : } \\
\text { - Sesuai prinsip atau nilai yang } \\
\text { dipegang. } \\
\text { - Sudah melekat ke diri (sudah jadi } \\
\text { sifat) } \\
\text { - Pilihan diri sendiri. } \\
\text { - Takut dosa. }\end{array}$ & & \\
\hline 3. & $\begin{array}{l}\text { Teman : } \\
\text { - Melihat teman } \\
\text { - Diberitahu teman }\end{array}$ & & \\
\hline 4. & & 55 \\
\hline
\end{tabular}

Faktor yang paling banyak memunculkan emosi moral adalah faktor orang tua dan faktor internal (diri sendiri).

Berdasarkan hasil penelitian longitudinal Krettenauer, Colasante, Buchmann, \& Malti (2014) pada remaja di Swiss menunjukkan bahwa perkembangan emosi moral diharapkan tidak terbatas pada anak-anak saja. Emosi moral berfungsi untuk menghubungkan antara perkembangan kepribadian moral dengan proses pengambilan keputusan pada perilaku moral sehari-hari.

Penelitian emosi sendiri akan lebih tepat apabila didasarkan pada pengalaman pribadi baik yang dilakukan sendiri ataupun yang dilihat berdasarkan apa yang dilakukan oleh orang lain. Pendapat tersebut sesuai dengan pendapat dari Rudolph (2013) bahwa emosi moral muncul karena reaksinya terhadap perilaku sendiri dan persepsinya terhadap perilaku orang lain. Berdasarkan pengalaman remaja itulah didapat informasi tentang pelanggran moral apa saja yang sudah dialami oleh remaja.

Pelanggaran moral yang paling banyak dilakukan remaja adalah masalah mencontek. Berdasarkan penelitian Murdock, Hale, \& Weber (2001) perilaku curang berkaitan dengan mencontek dipengaruhi oleh motivasi akademik siswa, self efficacy akademik, orientasi tujuan ekstrinsik, struktur partisipasi, komitmen guru, dan rasa hormat pada guru. Menurut hasil penelitian dari Newstead et al (1996) remaja putra lebih banyak mencontek disbanding remaja putri. Sedangkan hasil penelitian ini menunjukkan bahwa prosentase perilaku mencontek 
antara remaja putra dan remaja putri relatif sama, artinya jenis kelamin tidak memiliki pengaruh terhadap munculnya perilaku mencontek.

Pelanggaran moral lain yang banyak muncul adalah perilaku bullying. Remaja menyampaikan bahwa perilaku bullying adalah perilaku yang biasa, bahkan berpendapat bahwa perilaku itu sebagai perilaku yang lucu. Perilaku mengejek sering dilakukan pada temannya dan perilaku itupun dilakukan juga oleh guru pada muridnya. Menurut hasil penelitian dari Perren, Gutzwiller-Helfenfinger, Malti, \& Hyme (2012). Sebanyak 516 remaja berusia 12-18 (57\% wanita) di Swiss melaporkan frekuensi keterlibatan dalam bullying dan sebagai korban. Sebagai pelaku bully $(14,3 \%)$, sebagai pelaku bully yang dulunya sebagai korban bully $(3,9 \%)$, dan sebagai korban $(9,7 \%)$. Pada pelaku bully, tidak memiliki ikatan dengan penalaran moral. Pada pelaku bully yang dulunya pernah sebagai korban menunjukkan bahwa sebenarnya mereka masih tahu mana perilaku yang tepat dan yang tidak melanggar aturan moral. Namun mereka sendiri tidak tahu mengapa bisa melakukan bully. Pada korban menunjukkan bahwa masih berorientasi pada sesuatu yang benar (yaitu, lebih empati) namun aturan-aturan moralnya kurang kuat. Perilaku berpacaran yang berisiko juga termasuk yang banyak dilakukan oleh remaja saat ini. Remaja lebih berani dalam melakukan aktivitas berpacaran. Situasi ini menunjukkan bahwa dekandensi moral pada remaja menjadi masalah yang penting dan perlu dilakukan penelitian lebih lanjut berkaitan dengan faktor apa saja yang dapat menyebabkan remaja melakukan pelanggaran moral.

Berdasarkan hasil penelitian ini, diperoleh informasi bahwa emosi moral pada remaja putra dan putri yang paling banyak dirasakan adalah sedih. Masa remaja adalah masa perubahan besar dan seolah seperti badai yang menyebabkan kekacauan perkembangan dan bertentangan keadaan emosional. Rasa bebas yang baru ditemukan sering menyebabkan remaja secara emosional mengalami turbulensi (Karnani \& Pomm, 2006). Emosi mengatur fungsi interaksi antara individu dan lingkungan mereka, mengorganisir dan memotivasi tujuan perilaku (Campos, Kampus, \& Barrett, 1989; Sullivan, Helms, Kliewer, \& Goodman, 2008). Hal ini disertai dengan memiliki rasa pemahaman apa yang sedang terjadi, dan merasa mampu memprediksi apa yang akan datang. Berdasarkan hasil penelitian dari Putri, Prawitasari, Hakim, Yuniarti, \& Kim (2012) pada 461 responden remaja (laki-laki : 188, perempuan : 273) sedih yang pertama dipersepsi oleh remaja Indonesia sebagai pelajaran hidup $(27,3 \%)$. Kedua, kesedihan dilihatnya sebagai gangguan $(14,3 \%)$ sedangkan kategori ketiga adalah untuk menganggapnya sebagai cara refleksi diri (12,8\%). Kategori yang tersisa menunjukkan bahwa remaja Indonesia juga melihat kesedihan sebagai bentuk motivasi, hambatan hidup, momen kenangan, dan terakhir sebagai pelajaran spiritual. Menurut hasil penelitian dari Sombuling, Zakaria, Seok, Ismail, \& Kim (2012) berdasarkan data yang dikumpulkan dari 1.021 remaja akhir di Malaysia. Penelitian ini telah mengidentifikasi empat (4) sumber utama peristiwa kehidupan yang memicu emosi sedih pada remaja Malaysia. 
Sumber sedih yang dirasakan remaja adalah peristiwa kematian dan kerugian, masalah keluarga, perilaku yang tidak diinginkan, dan peristiwa kehidupan yang negatif. Emosi yang menyedihkan adalah perasaan subjektif dari bahagia, motivasi yang kuat untuk perilaku (melarikan diri atau melawan), dan fisiologis atau gairah respon yang kompleks.

Bingung juga merupakan emosi yang banyak dirasakan oleh remaja. Emosi lain yang ditandai dengan perasaan ketidakpastian, kebingungan apa yang terjadi, dan merasa yakin tentang apa yang akan terjadi dirasakan oleh remaja (Ellsworth \& Smith, 1988; Brinol, Barden, \& Petty, 2007 dikutip dari Putri et al, 2012). Konflik emosional seperti marah dan kesedihan, adalah salah satu emosi terkuat yang mengambil bagian dalam kehidupan remaja Putri, et al (2012).

Takut merupakan peringkat tiga dari emosi yang muncul pada remaja. Ditton,Bannister,Gilchrist, \& Farral (1999) 'ketakutan' adalah istilah yang mencakup berbagai perasaan yang membingungkan, perspektif, risiko-estimasi, sehingga antara satu dengan orang lain akan berbeda. dan yang dengan demikian berarti hal yang berbeda untuk orang yang berbeda. Emosi kemarahan yang muncul pada individu pelaku kejahatan merupakan konsep tentang ketakutan akan kejahatan yang telah dilakukan. Sama halnya dengan yang ditemukan pada penelitian ini. Perasaan takut muncul karena remaja tidak berani menghadapi risiko bila dimarahi orangtua atau pihak lain karena sudah melanggar aturan.

Emosi terbanyak yang muncul pada saat cerita perkelahian adalah merasa bingung. Kata bingung menurut Kamus Bahasa Indonesia berarti hilang akal (tidak tahu yang harus dilakukan), tidak tahu arah (mana barat mana timur dan sebagainya); tidak tahu jalan, gugup tidak keruan, bodoh; tolol, (merasa) kurang jelas (tentang sesuatu), dan kurang mengerti. Sesuai dengan karakteristik remaja yang masih mengalami kebingungan dalam menentukan pilihannya. Remaja putri banyak yang merasa bingung dan sedih menghadapi perkelahian. Emosi yang banyak muncul pada cerita mencontek pada remaja putri adalah takut, sedih, dan bingung. Remaja putri merasa takut bila perilakunya diketahui oleh guru dan mendapat sangsi. Sedangnya yang cukup menarik adalah pada remaja putra. Remaja putra senang karena ada kesempatan untuk mencontek dan merasa biasa saja dan tidak muncul rasa bersalah. Kondisi ini membuat remaja putra diprediksi akan melakukan lagi tindak kecurangan lain. Reaksi emosi remaja putri yang muncul saat mengahadapi persoalan bullying adalah sedih, bingung, prihatin, kecewa, marah, takut, dan jengkel. Namun demikian justru pada remaja putra yang banyak muncul adalah sedih, prihatin, kasihan, biasa saja, dan justru senang. Remaja mendapat contoh dari orang dewasa dalam berperilaku. Ada kecenderungan menganggap bullying sebagai perilaku biasa. Emosi takut banyak muncul pada remaja saat berbohong pada orangtuanya. Remaja putri merasa bersalah karena telah berbohong. Namun remaja putra tidak merasa bersalah bila harus berbohong pada orangtua. Namun gelisah pada saat berbohong. Remaja puri banyak merasa jijik, sedih, takut, dan prihatin berkaitan dengan 
perilaku menonton film dewasa (porno). Namun demikian, remaja putra banyak yang tidak jijik dalam menghadapi persoalan film dewasa.

Berdasarkan hasil penelitian, dapat diketahui bahwa faktor yang paling banyak menginspirasi munculnya emosi moral adalah faktor orang tua. Bagaimana orang tua mengasuh anak dapat membantu untuk menumbuhkan emosi moral yang berorientasi pada orang lain seperti simpati maupun emosi moral lainnya seperti rasa bersalah (Kochanska, Forman, Aksan, \& Dunbar, 2005; Kochanska, Koenig, Barry, Kim, \& Yoon , 2010; Krettenauer, Malti, \& Sokol, 2008). Anak-anak yang diasuh oleh orang tua yang suportif akan mampu mengekspresikan emosi moral lebih banyak daripada anak-anak yang diasuh oleh orang tua yang kurang mendukung. Interaksi di dalam keluarga yang memberi kesempatan anak untuk mengamati, yang saling mendorong sensitivitas dan responsif dapat menumbuhkan simpati anak (Zhou Eisenberg, Losoya, Fabes, Reiser, Guthrie, Murphy, Cumberland, \& Shepard, 2002). Van IJzendoorn (1997) mengemukakan bahwa orang tua yang mendukung dapat menciptakan suasana emosional di mana anak-anak mengembangkan kemampuan mengambil peran dan memahami kebutuhan emosional orang lain.

Faktor diri sendiri juga merupakan faktor yang kuat menginspirasi munculnya emosi moral. Prinsip-prinsip yang menjadi pegangan remaja dalam bertindak terwujud dalam karakter yang muncul dalam diri atau pribadi remaja. Sejauh mana pentingnya menjadi orang bermoral bagi identitas individu merupakan definisi dari identitas moral (Hardy \& Carlo, 2011). Jika individu merasa bahwa nilai moral seperti bersikap jujur, penyayang, adil dan murah hati sangat penting untuk menentukan identitas pribadi mereka, maka mereka memiliki identitas moral yang kuat. Identitas moral mulai muncul antara awal masa remaja dan masa dewasa. Pada umumnya remaja mulai mengintegrasikan nilai-nilai moral ke dalam dirinya selama masa remaja (Krettenauer \& Hertz, 2015) dan identitas moral dapat mempengaruhi munculnya emosi moral (Casey, 2004; Stets \& Carter, 2012). Selain itu, ada beberapa hasil penelitian, yang menghubungkan antara faktor internal remaja dengan emosi moral yaitu variabel kepribadian seperti pribadi perfeksionis akan berhubungan dengan perasaan malu, rasa bersalah, dan bangga (Tangney, 2000), harga diri berhubungan dengan rasa bangga dan malu (Tangney \& Fiscer, 1995), dan self-construal dapat mendorong munculnya ekspresi emosi spesifik (Aaker \& Williams, 1998; Kitayama, Mesquita, \& Karasawa, 2006; Markus \& Kitayama, 1991; Matsumoto, 1989).

\section{KESIMPULAN}

Emosi moral dapat muncul dalam menanggapi dilema moral hipotetis dan dapat berfunsgi sebagai antisipasi untuk berperilaku moral. Emosi moral dapat menjadi motivasi untuk mencapai kesejahteraan orang lain bukan hanya si pelaku saja. Pelanggaran moral yang banyak dilakukan remaja sekarang ini adalah mencontek, bullying, perilaku pacaran berisiko, menonton film porno, melanggar peraturan lalu lintas dan sekolah, berbohong, 
membantah, perkelahian, dan mencuri. Emosi moral yang muncul adalah takut, sedih, bingung, prihatin, merasa bersalah,jijik, gelisah, kecewa, biasa saja, kasihan, kawatir, dan senang. Berdasarkan studi awal ini, peneliti menemukan emosi yang khas yaitu prihatin dan miris, dan biasa saja atau tidak merasakan apapun. Faktor yang paling kuat menginspirasi munculnya emosi moral adalah pengaruh orang tua melalui ajaran dari orang tua, kedekatan orang tua pada anak, kehangatan orang tua, dukungan orang tua. Faktor internal juga mempengaruhi munculnya emosi moral. Remaja melihat bagaimana orang tua merespon suatu peristiwa dan emosi yang dimiliki orang tuanya. Remaja akan memegang ajaran orang tua untuk diinternalisasikan ke dalam dirinya dan hal tersebut menjadi hal yang penting. Memiliki identitas moral yang kuat berarti remaja merasa bahwa menjadi orang yang bermoral merupakan hal yang penting bagi identitas dirinya dan dapat mempengaruhi munculnya emosi moral.

Penelitian ini masih perlu dikembangkan dengan menggunakan metode cross sectional untuk mengetahui perkembangan pada masing-masing usia, meneliti lebih mendalam pengaruh orang tua dalam menumbuhkan emosi moral,dan meneliti pengaruh faktor internal dengan ( seperti nilai yang dipegang atau standart moral, karakter, dan identitas moral).

\section{DAFTAR PUSTAKA}

Aaker, J., \& Williams, P. (1998). Empathy versus pride: The influence of emotional appeals across cultures. Journal of Consumer Research, 25, 241-261.

Borba, M. (2001). Building moral intelligence : The seven essensial virtues that Teach Kids to do the right thing. San Fransisco : Josey - Bass.

Casey, V.(2014).Positive Moral Emotions and Moral Identity Development: The Difference between Authentic and Hubristic Pride.Theses and Dissertations (Comprehensive). 1675.http://scholars.wlu.ca/etd/1675.

Desmita.(2005).Psikologi perkembangan. Bandung : Remaja Rosdakarya.

Ditton,J., Bannister,J.,Gilchrist,E., \& Farral.S.(1999).Afraid or angry? Recalibrating the "fear"or crime. International Review of Victimology, 6, 83-99.

Fiske, A. P. (2002). Socio-Moral Emotions Motivate Action to Sustain Relationships. Self and Identity, 1, 2, 169-175. doi:10.1080/152988602317319357.

Greene, J. (2003). From neural "is" to moral "ought": what are the moral implications of neuroscientific moral psychology? Nature reviews. Neuroscience, 4(10), 846-849. doi:10.1038/nrn1224.

Haidt,J. (2003). The Moral Emotions. In: R. J. Davidson, K. R. Scherer, \& H. H. Goldsmith (Eds.) Handbook of affective sciences (pp. 852-870). Oxford: Oxford University Press. 
Hardy, S., \& Carlo, G. (2011). Moral identity: What is it, how does it develop, and is it linked to moral action? Child Development Perspectives, 5, 212-218. doi:10.1111/j.17508606.2011.00189.x

Irawan, S.(2007).Metode dan penelitian sosial. Jakarta : Bumi Aksara.

Jia,F.(2008). Moral Emotion expectancies in adolescence : A cross-cultural perspective. Thesis.University of Winnipeg.

Karnani, H., \& Pomm, H. (2006). Screening for adolescent depression and anxiety in the primary care environment: Calming the storm within. Northeast Florida Medicine, 57, 41-46.

Kitayama, S., Mesquita, B. and Karasawa, M. (2006), "Cultural affordances and emotional experience: socially engaging and disengaging emotions in Japan and The United States", Journal of Personality and Social Psychology, Vol. 91 No. 5, pp. 890-903.

Kochanska, G., Forman, D. R., Aksan, N., \& Dunbar, S. B. (2005). Pathways to conscience: Early mother-child mutually responsive orientation and children's moral emotion, conduct, and cognition. Journal of Child Psychology and Psychiatry, 46, 19-34.

Kochanska, G., Koenig, J., Barry, R.A., Kim, S., \& Yoon, J.E. (2010). Children's conscience during toddler and preschool years, moral self, and a competent, adaptive developmental trajectory. Developmental Psychology, 46 (5), 1320-1332. doi:10.1037/a0020381.

Krettenauer,T., Colasante, T., Buchmann, M. \& Malti, T.(2014). The Development of moral emotions and decision-making from adolescence to early adulthood: A 6-Year longitudinal study. Journal Youth Adolescence, 43, 583-596. doi 10.1007/s10964-0139994-5.

Krettenauer,T. \& Hertz, S.2015. What Develops in Moral Identities? A Critical Review. Human Development, 58, 137-153.doi: 10.1159/000433502.

Krettenauer, T., Malti, T., \& Sokol, B. (2008). The development of moral emotions and the happy victimizer phenomenon: a critical review of theory and applications. European Journal of Developmental Science, 2, 221-235.

Lewis, M. (2008). Self-conscious emotions: Embarrassment, pride, shame, and guilt. In Michael Lewis, J. M.Haviland-Jones, \& L. F. Barrett (Eds.), Handbook of emotions (3rd ed., pp. 742-756). New York: Guilford Press.

Lickona, T.(1999). Moral stages and moralization : the cognitive developmental approach. New York : $\mathrm{HOH}$, Reehart \& Winston.

Newstead, S. E., Franklyn-Stokes, A., \& Arrnstead, P. (1996). Individual differences in student cheating. Journal of Educational Psychology, 88, 229-241.

Markus, H.R., \& Kitayama, S. (1991). Culture and the self: Implications for cognition, emotion, and motivation. Psychological Review, 98(2), 224-253. 
Matsumoto, D. (1989). Cultural influences on the perception of emotion. Journal of CrossCultural Psychology. 20(1), 92-105.

Monks, F. J. , Knoers, A. M. P. , \& Haditono, S. R. (2000). Psikologi Perkembangan: Pengantar dalam berbagai bagiannya. Yogyakarta: Gadjah Mada University Press.

Murdock,T.B., Hale,N.M., \& Weber,M.J.(2011). Predictors of Cheating among Early Adolescents: Academic and Social Motivations. Contemporary Educational Psychology, 26, 96-115.

Muslich, M.(2013). Pendidikan karakter menjawab tantangan krisis multidimensional.Jakarta : Bumi Aksara.

Perren, S., Gutzwiller-Helfenfinger.E., Malti,T, \& Hyme, S.(2012). Moral reasoning and emotion attributions of adolescent bullies, victims, and bully-victim. British Journal of Developmental Psychology,30,4. 511-530.doi : 10.1111/ji.2044-835X.2011.02059.x.

Putri,A.K., Prawitasari,J.E., Hakim,M.A., Yuniarti,K.W., \& Kim,U.(2012). Sadness as perceived by Indonesian male and female adolescents. International Journal of Research Studies in Psycholoy, 1 ,1,27-36. doi: 10.5861/ijssp.2012.v1i1.22.

Rest, J., Narvaez,D., Bebeau,M. \& Thoma, S.J. (1999). Postconventional moral thinking: A neo-Kohlbergian approach. Mahwah, NJ: Lawrence Erlbaum Associates.

Rozin, Lowery, Imada, \& Haidt.(1999). The CAD triad hypothesis : A mapping between three moral emotions (contempt, anger, disgust) and three moral codes (community, autonomy, divinity). Journal of Personality and Social Psychology,4, 574-586.

Rudolph,U., Schulz,K.,\& Tscharaktschiew, N.(2013). Moral emotions : An Analysis guided by heider's naïve action analysis.International Journalof Advances in Psychology (IJAP),2. 2. www.ij-psychol.org.

Santrock, J.W. (2003). Adolescence perkembangan remaja (ed.6). Jakarta : Penerbit Erlangga.

Sawyer, S.M., Azzopardi,P.S., Wickremarathne,d., \& patton,G.C.(2018). The age of adolescence. The Lancet Child \& Adolescent Health,2(3), 223-228.doi: https://doi.org/10.1016/S2352-4642(18)30022-1

Shaffer, D.R., \& Kipp K. (2014). Developmental Psychology Childhood and Adolescence (ed.9). United States : Cengage Learning.

Sigelman,C.K.\& Shaffer,D.R.(1991). Life-span human development. California : Brooks/Cole Publishing Company Pacific Grove.

Sombuling,A., Zakaria,S., Seok,C.B., Ismail,R., \& Kim.U.(2012). Sadness from the Perspectives of Adolescents in Malaysia. Proceeding International Conference on Psychological Sciences and Behaviors (ICPSB 2012). Diunduh tanggal 10 Oktober 2016 dari http://www.ipedr.com/vol40/025-ICPSB2012-P10018.pdf. 
Stests, J.E. \& Turner, J.H.(2006). Handbook of the sociology of emotions. United States of Amerika : Springer Science+Business Media,LLC.

Stets, J.E. \& Carter,M.J.(2012). A Theory of the Self for the Sociology of Morality. American Sociological Review, 77(1) 120-140.doi: 10.1177/0003122411433762.

Tangney, J. P.(2002). Perfectionism and the self-conscious emotions: Shame, guilt, embarrassment, and pride. In G. L. Flett, \& P. L. Hewitt (Eds.), Perfectionism: Theory, research, and treatment (pp. 199-215). Washington, DC US: American Psychological Association. doi:10.1037/10458-008.

Tangney,J.P. \& Dearing,R.L.(2004).Shame and Guilt.New York : The Guilford Press.

Tangney, J. P., \& Fischer, K. W. (1995). Self-conscious emotions: The psychology of shame, guilt, embarrassment and pride. New York: Guilford Press.

Tangney,J.P., Stuewig, J. \& Mashek,D.J.(2007). Moral emotions and moral behavior. Annual. Rev. Psychology, 58, 345-72.

Tangney,J.P. \& Tracy,J.(2011). Self-conscious emotions. Dalam Leary, M., \& Tangney, J.P. (Eds) Handbook of self and identity. New York: Guilford Press.

Van IJzendoorn, M.H. (1997). Attachment, emerging morality, and aggression: Toward a developmental socioemotional model of antisocial behaviour. International Journal of Behavioral Development, 21, 703-727.

Weiner, B. (2006). Social motivation, justice, and the moral emotions : an attributional approach. Social motivation justice and the moral emotions An attributional approach. Mahwah, NJ US: Lawrence Erlbaum.

Zhou, Q., Eisenberg, N., Losoya, S., Fabes, R. A., Reiser, M., Guthrie, I. K., Murphy, B.,Cumberland, A., \& Shepard, S. A. (2002). The relations of parental warmth and positive expressiveness to children's empathy-related responding and social functioning: A longitudinal study. Child Development, 73, 893-915. 